Discussion - a countrv report

\title{
Conceptual roots for innovation and innovativeness of the economy in Poland
}

\author{
Danuta Strahl ${ }^{1 *}-$ Roman Sobczak $^{1}$ \\ ${ }^{1}$ Wrocław University of Economics, Faculty of Economy, Management and Tourism, \\ Nowowiejska 3, 58-500 Jelenia Góra, Poland \\ *danuta.strahl@ue.wroc.pl
}

\begin{abstract}
The purpose of the article is to provide the evolutionary review and systemization of the basic concepts related to innovation and innovativeness in Polish research on regional economics and development. The emphasis is placed on the types of innovation and innovativeness of the economy and the main conceptual and practical sources for the innovation and innovativeness concept are being discussed within the framework of European regional policy.
\end{abstract}

Key words: human resources, science and technology, economic development, innovation, innovativeness

- The general features of the innovation and innovativeness concept are presented and its implication for planning are explained.

- The critical review of national and otherwise hardly accessible literature on roots of the innovation and innovativeness concept in Poland is provided.

Received: 3 Feb 2017 - Received in revised form: 15 May 2017 - Accepted: 26 May 2017

\section{Introduction}

The process of globalization and the emergence of new and dynamically developing economies in China, India and Brazil resulted not only in their higher economic but also political importance. Competing on the international arena imposes searching for new solutions, indispensable for achieving a stable and long-term economic growth. The key role in globalization processes is played by multinational enterprises. Their operations extend, by far, their country borders since they go along with the international movement of capital, knowledge and technology. The process of globalization functions as a strong incentive for innovation as well. International competition forces companies to increase their efficiency and to develop new products. Globalization can also change the sector structure of economies forcing them to develop new sectors and to change their institutional systems.

The need for more competitive European economy resulted in the development of the
Lisbon Strategy ${ }^{1}$ in 2000 and the Europe $2020^{2}$ strategy in 2010. The existing competition between countries and regions, in terms of material resources, is being displaced by the competition of non-material resources, and primarily by human resources. It means that the development opportunities result, to a much greater extent, from human intellectual potential and knowledge related to the most recent achievements of modern science. Currently economists agree that human capital represents one of the primary factors responsible for economic growth.

The role of human capital in innovation oriented activities is crucial not only at the level of particular firms, but also on an aggregated level. Some interesting problems related to human capital are as follows: the quality of education system and its adjustment to the innovation needs of business and other entities; the activities undertaken by companies in order to invest in human capital ingrained in employees; 
the need for halting innovative activities due to the qualified personnel shortage; the sufficient opportunities in providing trainings for employees; the level of workers' flexibility in adjusting to the labour market structure, as well as their mobility in regions and sectors. The methods measuring human capital role in innovations remain, however, insufficiently developed and the statistical research covering innovations result in limited information in this matter.

The purpose of the article is to review and systematize the basic concepts related to innovation and innovativeness. The emphasis is placed on the types of innovation and innovativeness of the economy.

\section{The essence and types of innovations}

The problems of innovation and innovativeness became scientifically popular in the mid-20th century (in the 40s and 50s), even though this concept was introduced by J.A. Schumpeter in 1911.

The word innovation originates from the Latin "innovates", i.e. renewal, creating something new. It is understood as "introducing something new and different, bringing a new item into use or operation for the first time, a novelty, a reform" (Tokarski 1980). The common understanding of this concept means something new and different from the existing solutions; it is associated with the necessary change for better (Janasz \& Kozioł 2007, p. 11) and is very often used as the synonym of "change".

The term "innovations", if approached in its broad sense, is referred to all spheres of life, starting from the new solutions in economy and the functioning of societies and ending with the new intellectual and cultural trends (Janasz \& Kozioł 2007, p. 23). Innovation refers to the implementation of a new or significantly improved product (good, service) or a process, a new marketing method or a new organizational method in an economic practice, in the organization of workplace or external relations (OECDEurostat 2005, p. 46). The above presented definition covers the broad spectrum of possible innovations. From a narrower perspective innovation can be categorized as the implementtation of one or several innovation types, e.g. innovation referring to a product or a process. Such narrower definition of innovation, covering products or processes, can be referred to the definition of technological innovations related to products and processes. It has been adopted that the minimum requirement for an innovation to occur is the novelty (or a significant improvement) of a product, process, a marketing method or an organizational method. It covers products, processes and methods developed by a given company for the first time, and also those adopted from other companies or entities.

For the first time the concept of innovation in economic sciences was introduced by J.A. Schumpeter. It is approached as the classical one and refers to six cases:

1. Launching a new product, brand new for the consumers or a new type of product, and also improving the already existing products;

2. Introducing a new production method, not yet practically tested in a particular industry sector or improving the existing manufacturing process;

3. Opening a new market, i.e. the one at which a given type of domestic industry was not operating at all and regardless of whether such market had or had not existed before;

4. Obtaining a new source of raw materials or semi-finished goods and regardless of whether such source has already existed or had to be developed;

5. Introducing new organization in some industry sector, e.g. establishing a monopoly or breaking it;

6. Applying a new method of sales or purchase (Schumpeter 1960, p. 104).

The above presented approach to innovation constitutes the broadly understood combination of different types of materials' production and workforce. Therefore the scope of innovation in J.A. Schumpeter's interpretation is quite extensive, whereas its timeframe remains narrow. It refers to the statement that an 
innovation represents just the original, economic realization of an invention inherent in its background. He focused primarily on technical innovations and their impact on economy. The definition by J.A. Schumpeter was the starting point for defining concepts covered by innovation oriented activities as well as scientific and technical progress (Mikosik 1993).

The following Polish researchers were studying the problems of innovation in the second half of the 20th century: K. Wandelt, J. Czupiała, L. Piaseczny, J. Więckowski, B. Fiedor, S. Kasprzyk, L. Białoń, Z. Pietrusiński, W. Spruch and Z. Madeja.

K. Wandelt defined innovations as using, for certain manufacturing purposes, either a discovery or an invention being the manifestation of inventiveness, which represents searching for and analysing focused on the development and verification of knowledge (Wandelt 1972).

W. Spruch related innovations to the technical sphere of human activity and identified novelty with something innovatory in a global scale. He defined technical innovation as a technical project applied in an industrial practice, including the stages of work directly related to its implementation (Spruch 1976, p. 37-38).

L. Białon defines innovation as the result of the first implementation in different spheres of human activity and also in the domain of science and technique. Innovations in the technical sphere refer to the production of new goods, starting new technological processes and organizational systems in order to achieve higher management efficiency (Białoń 1976).

J. Czupiał referred to innovation as subject to creating and launching a new product or an economic application of a new process for manufacturing the already existing products (Czupiał 1988, p. 50).

The international methodological recommendations covering innovation measurement, as well as the methods for structure analysis and changes occurring in it were presented in the Oslo manual: Guidelines for Collecting and Interpreting Innovation Data. The manual publication results from the cooperation of
Eurostat, OECD, UNESCO and also a group of international experts.

The statistical research on innovations can become the source of an extensive collection of data describing the process of innovation at an enterprise level. They can identify both motives and obstacles in undertaking innovation oriented activities, changes in an enterprise functioning, types of initiating innovative activities, as well as the types of implemented innovations. If an innovation oriented process is approached as a systemic one statistical studies can represent the source of information about the relationships between companies and other participants of economic processes and also the methods used in protecting their innovations.

The analysis of innovations can emphasize the specific types of information useful in innovation activities, as well as the types of institutions and communication mechanisms available for business. It covers the data on the sources of information, knowledge and technology transfers, the cooperating partners and barriers hindering innovations due to information gaps, e.g. those referring to technologies or markets.

The particularly interesting issue, from the perspective of innovation policy, is the impact of innovation on the production volume, productivity and employment at the domestic level and in the specific sectors or regions. The information about factors influencing success can result in developing better policy aimed at taking economic and social advantages of innovations.

In accordance with the Oslo Manual: Guidelines for Collecting and Interpreting Innovation Data, 3rd Edition four types of innovation can be distinguished: product innovations, process innovations, marketing innovations and organizational innovations.

Product innovation refers to the introduction of a product or a service which is new or significantly improved in terms of its features or applications. It covers the significant improvements referring to technical specification, components and materials, software, easy usage or other functional characteristics. Product innova- 
tions (related to products) can take advantage of the new knowledge or technologies or be based on new applications or combinations of the existing knowledge and technologies. The term "product" refers to both products and services. Product innovations cover launching new products and services, as well as the significant improvements of the existing goods and services regarding their functional or utility properties.

New products represent goods or services which are significantly different in terms of their features or purpose from those produced so far by the company.

The first integrated circuits and digital devices can serve as the examples of the new products applying new technologies. The first laptops, which combined the current software standards with the technology of hard discs miniaturization, represented a new product combining the existing technologies.

The development of new product application, introducing only slight changes in its technical specification, represents product innovation. Launching a new detergent, along with the already known chemical composition, previously used as a semi-product only, can be an example here.

The introduction of ABS breaking system, GPS navigation systems or other improvements within the framework of automotive sub-components represent the examples of product innovations consisting in partial changes or supplementing one of many integrated technical subcomponents. Another example of product innovation in the development of mobile phones is the usage of cameras and camcorders in mobile phones. The application of such solution allowed for adding a new, additional function to a mobile phone, i.e. a camera. Product innovations can also be noticed in food industry, e.g. the production of food offering new functional qualities - margarine reducing the level of cholesterol in blood, or yoghurts containing live bacteria facilitating digestion and supporting the proper digestive system functions. The usage of "breathing" fabrics in clothes remains yet another example of product innovation consisting in taking advantage new fabrics which improve product functioning. The above-mentioned changes present the feature of a significant improvement introduced into the already existing product related to changes in materials, components and other characteristics ensuring better functioning of these products.

Product innovations in the service sector can consist in introducing significant improvements in the method of services rendering (e.g. in their better efficiency or faster provision), in adding new functions or qualities to the already existing services, or introducing the entirely new services. The improvements in online banking, such as much faster facility and its simple usage can serve as an example. Still another one is offering bike rentals by some cities, along with the option of renting and returning a bike at any place in the city, which increases, by far, the residents' access to such services. Establishing contact points for the local population outside the Town Office, e.g. in shopping centres is another example influencing the residents' satisfaction and upgrades work quality in case of services outsourcing. Another example of a service oriented innovation is the possibility of making online payments - currently it is possible to pay for a product purchased on an online auction directly through a www site, whereas several years ago a customer had to visit a post office or a bank to make a transfer.

Design work is an integral part of the creation and implementation process for product innovations. A product innovation, however, does not refer to changes which do not result in a significant improvement of product functional features or its applications. Such changes can, nonetheless, be considered marketing innovations, which is discussed in the further part of the article. Routine updates and regular seasonal changes are also not referred to as product innovations.

Process innovation, i.e. an innovation covering a process represents the implementation of a new or significantly improved production or supply method. This category includes significant 
changes within the framework of technology, devices and/or software. Process innovation can help in reducing production or supply unit costs, quality upgrading, manufacturing or delivery of new or significantly improved products.

Production methods refer to techniques, devices and software used for manufacturing goods or providing services. The implementation of new devices for the production process automation within the framework of production line, or the implementation of computer support for the needs of designing and developing products can serve as examples of the new production methods.

Delivery methods refer to company logistics and cover devices, software and techniques used in the acquisition of production means, resources allocation in a company or the supply of finished goods. The implementation of the system for the movement of goods based on bar codes, or the application of chips for radio identification of goods to keep track of the materials movement through the supply chain are the examples of new delivery methods.

Design innovations also cover new or significantly improved techniques, devices and software in auxiliary activities such as supply, accounting, the provision of IT services and maintenance works. The implementation of new or significantly improved ICT represents an innovation within the framework of processes if it aims at quality upgrading of operations' efficiency.

Process innovations include new or significantly improved methods for developing and rendering services. They can consist in significant changes covering equipment and software used in service provision companies or in changes within the framework of procedures and techniques applied in rendering such services. The examples in this case are as follows: the implementation of GPS based location devices in transport services, or the introduction of a new booking system in a travel agency, as well as the development of new project management techniques in a consulting company.
Marketing innovation represents a new marketing method resulting in significant changes of a product design/construction, and also in packaging, distribution, promotion or pricing strategy.

The purpose of marketing innovation is to meet customer needs in a better way, to open new sales markets, or the new product positioning on the market in order to increase sales.

The distinguishing characteristics for marketing innovations, among other changes in terms of marketing instruments used by a company, is the fact that they consist in a marketing method implementation which, as yet, has not been applied by a given company. It has to remain the component of a new concept or a marketing strategy representing a significant change from the marketing methods applied so far. The new marketing method can be developed by an innovative company itself or adopted from other companies or entities. New marketing methods can be implemented for the needs of either the new or the already existing products.

Marketing innovations include the significant product design improvements representing the component of a new marketing concept. The above-mentioned product design transformations consist in changing the form and appearance of products, which do not result in changing their function or usage. This group also covers changes in the packaging of such products as food, beverages and cleaning supplies, in case of which packaging remains the decisive factor about the particular product image. The significant change in furniture aimed at giving it a new look and higher attractiveness can be an example of product oriented marketing innovation. Product design innovation can also refer to the significant changes introduced in the form, appearance or taste of food or beverages, e.g. the new flavours of foodstuffs to attract the new segment of clients.

Another example of marketing innovations is the introduction of significant changes in designing juice packaging, or the line of cosmetics in order to make them look more elegant and improve sales. 
New marketing methods in terms of product placement consist primarily in the introduction of new sales channels. Here sales channels represent methods applied in order to sell goods and services to clients, however, they do not cover logistics methods (transport, storage and handling products), since the latter is mainly related to efficiency upgrading.

The examples of marketing innovations in terms of product distribution are as follows: the first introduction of franchising system, direct sales or exclusive retail sales and also the introduction of product licensing. Product distribution innovations also cover the application of new product exposition concepts. Opening furniture showrooms, the arrangement of which is thematically changed, which allows clients to see products in the fully furnished interiors can serve as the example.

New marketing methods in terms of product promotion consist in using new concepts for promoting company products and services. For example a marketing innovation takes the form of the first application of the significantly changed carriers/media or techniques - such as product placement in films or TV shows, or a celebrity endorsing a product as its user. Branding is another example here, i.e. creating and introducing a totally new brand symbol (contrary to the regular adjustments in the brand image), or company product positioning on the new market, or giving a new image to a product. The introduction of personalized information system can be referred to as marketing innovation, e.g. loyalty or membership cards, as well as the first application of a special offer in a shop or a club, which is available only for the loyalty card owners of this particular shop.

Pricing innovations consist in applying new pricing strategies to sell company goods or services on the market. The example here is the first application of the new price adjustment method of a product or service depending on demand (e.g. when the demand is low the price is also low), or introducing the new method which allows clients to choose the desirable features of a product on the company website and next checking the price of the selected combination of a particular product attributes. The new pricing methods, the only purpose of which is to introduce variations in prices for the particular segments of clients, are not recognized as innovations.

Seasonal changes, regular or other routine ones in terms of marketing tools are generally not considered marketing innovations. In order to list them in this category they should refer to the marketing methods which have not been applied by the company so far. For example, a significant change of a product construction or packaging, based on the marketing concept which has been previously used by the company for other products does not represent a marketing innovation. Similarly, using the existing marketing methods in order to reach a new geographical market or a new segment of clients (e.g. a group of buyers characterized by the specific sociodemographic features) is not recognized as an innovation.

Organizational innovation represents the implementation of a new organizational method, following the business practices adopted by a company, in the workplace organization, or in external relations. The purpose of organizational innovations is to achieve better results by reducing administration or transactional costs, increasing work satisfaction level (and thus work efficiency), getting access to the non-tradeable assets (such as non-codified external knowledge) or reducing delivery costs.

Organizational innovations do not cover changes related to the adopted functioning rules, workplace organization or in external relations, which are based on the organizational methods used by the company in the past. Developing a management strategy cannot be regarded as an innovation either. On the other hand, organizational changes implemented in response to a new management strategy are recognized as an innovation, if it is the first implementation of a new organizational method referring to the business practices, workplace organization or external relations. For example, the introduction 
of a strategic document in a written form and aimed at the improvement in the effective usage of knowledge in a company is not an innovation itself. However, it represents an innovation when this strategy is implemented as a result of applying new software and the rules for documenting information in order to stimulate knowledge sharing between different branches of the company.

The distinguishing factor of organizational innovation, comparing to other organizational changes in a company is the application of such organizational method (within the business practices adopted by a company, in a workplace organization or in external relations), which has not been used so far in a particular company and which results from the strategic decisions made by its management.

Organizational innovations within the framework of the business practices adopted by a company consist in the implementation of the new methods for organizing routine activities and procedures regulating company operations. It covers e.g. the implementation of new practical rules aimed at improving the learning process and sharing knowledge inside the company. The first implementation of practical rules for knowledge codification, e.g. the development of best business practices base, the conclusions drawn and other knowledge to allow other people an easy access to such base, can serve as the example. Another example takes the form of the first implementation of business practices aimed at employees' development and improvement of the personnel retention rate, e.g. education and training systems. Still another example is the first implementation of production or supply management systems, e.g. the systems for supply chain management, as well as business reengineering, or lean production systems and also quality management systems.

Innovations referring to workplace organization consist in the implementation of new methods for the division of tasks and decision-making powers among employees in order to divide work in divisions and between them (and organizational units). The example of such innovation can also take the form of the implementation of new concepts in activities structuring, e.g. the integration of different types of business operations. The example of an organizational innovation related to workplace organization is the first implementation of an organizational model which ensures more extensive autonomy of company staff in making decisions and encourages them to share their ideas with colleagues. It can be achieved by decentralizing group activities and managerial control, or by appointing formal or informal workgroups within the framework of which business duties of particular employees are specified in a more flexible way. Organizational innovations can also take the form of business operations' centralization and taking bigger responsibility for the decision made. The introduction of build-to-order production systems for the first time is an example of an organizational innovation in the area of business operations structuring. Another example is the integration of sales and production or the integration of design and development works with production. New organizational methods in terms of external relations consist in the implementation of new methods for organizing business relations with other enterprises or public institutions, e.g. initiating new types of cooperation with R\&D centers or clients, new integration methods with suppliers, as well as the first outsourcing order or subcontracting such business components as manufacturing, supplies, distribution, recruitment or auxiliary services.

Mergers with other businesses and takeovers of other companies do not represent organizational innovations, even if a company performs a merger or a takeover for the first time. Mergers and takeovers can, however, result in organizational innovations if, in the course of a particular process, a company develops or implements new organizational methods (OECDEurostat 2005, p. 47-52)

Recently eco-innovations have also been distinguished, sometimes referred to as "green innovations". They, however, do not represent an 
additional category, but the inherent feature of some innovations. Eco-innovations take the form of both new products (including services) and new manufacturing processes (Jasiński 2014, p. 11)

\section{The concept of economy innovativeness}

Apart from the concept of innovation also the terms of innovativeness and innovative are functioning in the theory and practice of social and economic life. Despite an extensive output of the theory of innovation many definitions of the basic categories covered by this theory can be noticed. It also refers to such terms as innovation, innovativeness and innovative. Currently it is difficult to define clearly the differences between the above terms. It can be assumed that innovativeness is the name given to a certain phenomenon and primarily the process of changes, innovative - is the feature of this process, whereas innovation - presents the outcome of implementing innovative changes (Markowska 2012, p. 46). It seems that such terms as novelty and reforming remain the closest in their meaning to the concept of innovativeness.

Innovativeness is understood as the characterristics which can be applied to entire societies, local communities, organizations, their parts and ultimately also to individual people.

Therefore it seems important to explain the concept of "innovativeness" at this point. According to P. Niedzielski innovativeness remains the "attribute of economic entities or economies and represents the ability to develop and implement innovations, as well as absorb them, and is associated with active involvement in innovation oriented processes, along with undertaking actions aimed at the above-mentioned processes; it also refers to the activities focused on obtaining resources and gaining skills indispensable to participate in these processes" (Niedzielski 2005, p. 74).

It can be adopted that if innovations represent activities which result in the high level of novelty or changes in the scale of an organization or entire economy, innovativeness should be recognized as an organization's (economy's) ability to create and implement novelty. Both individual innovations and innovativeness represent complex processes requiring intellecttual involvement (research, studies and discussions) and also implementation skills. In the course of an efficiently functioning innovation process the above-mentioned two types of operations can or even should overlap (Włosiński 2007, p. 46).

Innovativeness of the economy represents the capacity and motivation of entrepreneurs to conduct scientific research aimed at the improvement and development of production, at investigating new solutions, ideas and concepts. Innovations in the economy result in the development of new products, in improving technologies, increasing business efficiency and thus higher competitiveness of the economy against other countries.

In the opinion of W. Dominik innovativeness of the economy defines the ability and willingness of economic entities for the continuous investigation and application of research results, R\&D work, new concepts, ideas and inventions in their business practice, but it is also manifested by an ongoing improvement and development of the already used technologies for both material and non-material production processes, for implementing new methods and techniques in an organization and management, for improving and developing infrastructure and extending knowledge resources (Dominik 2007, p. 67). Innovativeness of the economy can refer to both the production and service sector and cover all factors aimed at the creation of new quality (OECD-Eurostat 1997).

In Poland innovativeness is identified with the application of R\&D results in the material and non-material production processes, with the cooperation of business and academic centres and also with new technologies (Stawasz 1999). It seems that such quite narrow interpretation characterizes accurately the method focused on upgrading innovativeness of the national economy. 
Technologies, patents, research and development work, presenting potential economic usefulness, remain the domain of natural and technical sciences. Therefore the highest expectations for generating innovative technologies, useful in the business practice, are addressed to these institutions which deal with natural and technical sciences. It seems, however, that such expectations are incorrectly addressed, since the development of new technologies in a systematic and organized manner does not decide about the existence of an academic centre and should not constitute the grounds for its functioning. It is a business itself which remains the natural generating force and an incentive in developing innovations, for which launching new, innovative products should be the condition of development and effective competition. The role of business in the process of creating innovation usually comes down to specify a new product and its characteristics, to identify market expectations, invest financial means and initiate production. In the course of innovativeness oriented process both academic and research centres can be observed as the suppliers of technologies and knowledge necessary for the technical processes underlying a given product manufacturing. The mechanism of innovativeness shall play an effective role provided the natural partnership does occur - mutually beneficial, between the sphere of science and economy (Dominik 2007, p. 68).

In accordance with the terminology used by OECD innovative activities represent operations of scientific, technical, organizational, financial and commercial nature, which aim at developing and implementing new or significantly improved processes and products.

The results of innovative activities can be as follows:

- developing the system which responds to the needs and problems of the job market within the framework of political and institutional structure;

- developing new methods, tools, new approaches and improving the already existing ones;
- determining new goals, identifying new and promising approaches, opening new paths for employment.

The technologically advanced countries achieved their development as a result of taking advantage of the global scientific achievements. The innovation oriented policy of these countries was focused e.g. on the creation of R\&D centres functioning at industrial enterprises. It opened opportunities for developing innovative products and processes. The functioning of such centres allowed for the business market position strengthening.

The research covering innovativeness is focused on the following two aspects: theoretical and methodological (definitions, typology and measurement) and also an empirical one (innovativeness level assessment).

\section{Conclusions}

In modern times the innovativeness of countries, regions and enterprises is of particular importance. Fast economic development of The Czech Republic and Poland is possible only based on knowledge, scientific research and new technologies. Currently the development of innovation in national economy remains one of the key challenges faced by the governments of our countries. It seems that innovations can play the vital role in long-term socio-economic transformations. Innovations have become the crucial factor explaining the reasons of differences in the achievements between countries, regions and companies. The businesses which take advantage of innovations are gaining an increasing advantage over their competitors. Innovating countries and regions achieve higher productivity and income than others. In such reality both The Czech Republic and Poland have to undertake all possible efforts to increase their investment activities in order to catch up with the innovation leaders represented in Europe by the Scandinavian countries and Germany.

Innovations are characterized by the tendency towards concentration in certain industry 
branches/sectors, which as a result develop faster and implement changes in production and manufacturing.

Both diversity and variety are indispensable to achieve success in the global economy. Any region can become an innovation centre, at least in terms of some industry sectors.

Innovation represents a global phenomenon, however, it is a region which decides about economic growth based on innovations. Regions offer the diversity of people, types of land and services. They ensure proper environment in which enterprises can have easy access to the specialized structure, educational institutions and workforce.

Upgrading both Czech and Polish innovativeness level is a long-term activity and requires adopting the appropriate strategy for innovation development by the governments of our countries.

\section{Notes}

${ }^{1}$ Lisbon Strategy - the development plan adopted for the European Union by the European Council at the meeting in Lisbon in 2000. Lisbon Strategy is a socioeconomic development plan of the European Union implemented in the period 2000-2010. The growing developmental disparities between the United States of America and Japan and the European Union Member States became the main reasons for this program development, as well as the need to address the challenges resulting from the increasing competition from the Asian countries and the problem of population aging. The European Council adopted that the strategic goal of the EU is turning the European Union into the most competitive and dynamic, knowledge-based economy worldwide over the next decade, ensuring sustainable economic growth, creating new jobs and social cohesion. The document clearly emphasizes the crucial role of research, innovation, ICT and investing in human resources in economic development.

2 "Europe 2020 - the strategy for smart, sustainable and inclusive growth" represents the new, long-term program for socio-economic development of the European Union in the years 2010-2020. It was adopted by the European Council on 17th June 2010 and replaced the Lisbon Strategy implemented in the period 2000-2010.

\section{References}

Białoń L (1976) Poziom techniczny a zatrudnienie w polskim przemyśle w układzie gałęziowym [Technical level vs. employment in Polish industry in a branch system], WPW, Warsaw.

Czupiał J (1988) Zarys metodologii planowania i oceny przedsięwzięć badawczo-innowacyjnych [The outline of planning methodology and the assessment of research and innovation projects], PWN, Warsaw.

Dominik W (2007) O innowacyjności - innowacje jako przedmiot obrotu gospodarczego. In: Określenie istoty pojęć: Innowacji i innowacyjności, ze wskazaniem aktualnych uwarunkowań i odniesień do polityki proinnowacyjnej - podejście interdyscyplinarne [About innovativeness - innovations as the component of economic turnover. In: Defining the essence of the concepts: innovation and innovativeness indicating the current determinants and references to the pro-innovative policy interdisciplinary approach], KIG, Warsaw.

Europe 2020 (2010) the strategy for smart, sustainable and inclusive growth, (2010) The Communication by the European Commission, Brussels.

Janasz W, Kozioł K (2007) Determinanty działalności innowacyjnej przedsiębiorstw [Determinants of innovation activities in enterprises], PWE, Warsaw.

Jasiński AH (2014) Innowacyjność w gospodarce Polski [Innovativeness in Polish economy], Wydawnictwo Naukowe Wydziału Zarządzania Uniwersytetu Warszawskiego [Scientific Publishers of the Faculty of Management at the University of Warsaw], Warsaw.

Markowska M (2012) Dynamiczna taksonomia innowacyjności regionów [Dynamic taxonomy of regional innovativeness], Wrocław University of Economics, Wrocław.

Mikosik S (1993) Teoria rozwoju gospodarczego Josepha A. Schumpetera [The theory of economic growth by Joseph A. Schumpeter], PWN Press, Warsaw.

Nowakowska A (2011) Regionalny wymiar procesów innowacji [Regional dimension of innovation processes], University of Łodź Press, Łódź.

OECD-Eurostat (1997) Oslo Manual: The Measurement of Scientific and Technological Active. Proposed Guidelines for Collecting and Interpreting Technological Innovation Data, European Commission, OECD Publishing, Paris.

OECD-Eurostat (2005) Oslo Manual: Guidelines for Collecting and Interpreting Innovation Data, 3rd Edition, OECD-Eurostat, Paris. 
Schumpeter JA (1960) Teoria rozwoju gospodarczego [The theory of economic development], PWN, Warsaw.

Spruch W (1976) Strategia postępu technicznego. Wstęp do teorii [The strategy of technical progress. Introduction to the theory], PWN Warsaw.

Stawasz E (1999) Innowacje a mała firma [Innovations and small business], University of Łodź Press, Łódź.

The European Council (2000) The Lisbon Strategy. The road to success of united Europe, Lisbon.

Tokarski J (1980) Słownik wyrazów obcych [The dictionary of foreign terms], PWN, Warsaw.
Wandelt K (1972) Stadia nad postępem technicznym i organizacyjnym [The study on technical and organizational progress], PTPN, Pozań.

Włosiński W (2007) Innowacje jako proces intelektualny i wdrożeniowy. In: Określenie istoty pojęć: innowacji i innowacyjności, ze wskazaniem aktualnych uwarunkowań i odniesień do polityki proinnowacyjnej - podejście interdyscyplinarne [Innovations as an intellectual and implementation process. In: Defining the essence of the concepts: innovation and innovativeness indicating the current determinants and references to the pro-innovative policy - interdisciplinary approach], KIG, Warsaw. 